\title{
Has Foreign Capital Made us Richer?
}

\section{Tony Makin}

A ustralia's current account deficit approached seven per cent of GDP in 2004-05, one of its highest ever levels, renewing concerns in financial markets and economic policy circles about the sustainability of the economy's balance of payments (see Edwards, 2005, Swan, 2005). External deficits of similar magnitude relative to GDP have recently been experienced by the United States, New Zealand and to a lesser extent by the United Kingdom. These deficits have been largely funded by high saving economies in East Asia, especially Japan and China, and oil exporting nations (see MacFarlane, 2005; International Monetary Fund, 2005).

Financial market traders and policymakers worry that current account deficits of this size reflect poor international trade performance; that imports are too high and exports are too low. In addition, escalating external debt levels are considered inherently risky because over-reliance on foreign funds exposes an economy to sudden shifts in international investor sentiment and hence to capital flow reversals that could precipitate a currency and financial crisis, spark high inflation and induce a major recession (see, amongst others, Mann, 2002; and Fischer, 2003).

The significance of current account deficits has been a long-running theme in Australian economic policy debate. As argued previously (Makin, 1989) at a time when the balance of payments was the central macroeconomic issue, external deficits are often best interpreted as saving-investment imbalances that allow real domestic capital accumulation to proceed more quickly. As a counter to concerns about external imbalances, it can therefore be argued that external deficits and matching capital account surpluses should actually be welcomed since they allow real investment to be higher. Similarly, in stock terms when foreign funds finance expansion of the domestic capital stock, the rise in external liabilities is matched by an increase in the level of productive plant, equipment and buildings.

In sum, irrespective of its form net capital inflow allows more domestic capital accumulation which, if used for this purpose, improves the economy's overall productive capacity. Numerous theoretical approaches have previously been advanced to demonstrate this (see, amongst others, Frenkel and Razin, 1987; McDougall, 1960; Grubel, 1987; Ruffin, 1987; and Makin, 2003).

In the resurgent economic policy debate about Australia's external imbalance, an important question not yet asked nor answered is: By how much has foreign capital raised Australia's living standards? Or, in other words, how much better off, income-wise, have persistent current account deficits and rising foreign debt levels made us? 
This paper addresses that question by providing estimates of national income gains attributable to capital inflow for the period 1995-96 to 2004-05. First however, it highlights the behaviour of saving and investment as influences on external account outcomes. It then proposes a straightforward method for understanding how capital inflow improves national income before estimating the national income gains that have accrued from the use of foreign capital over the past decade.

\section{Saving, Investment and the External Imbalance}

Australia's current account deficit has averaged 4.5 per cent of GDP since the early 1990s and on this measure has been one of the largest long-running deficits in the world. Historically, these imbalances have resulted from the nation's status as a relatively low saving economy, yet one that persistently invests comparatively more than other comparable economies (see Figure 1).

External imbalances have been the measured equivalent of the excess of domestic investment (expenditure by the private and public sectors on fixed assets including machinery and equipment, dwellings, non-dwellings, roadworks and livestock) over relatively more stable domestic saving, as shown in Figure 1. This figure also reveals how much extra domestic investment capital inflow has financed over and above that funded by domestic saving. Moreover, since saving has been relatively stable, the bulk of variation in the external imbalance has been due to fluctuation in investment.

A significant portion of gross saving is devoted to capital consumption, or depreciation. However, annual saving-investment gaps still have the same value shown in Figure 1 when capital consumption is subtracted from the depicted gross saving and investment measures. Net domestic saving has remained positive since the early 1990s and was around five percent of GDP in 2004-05. Capital inflow therefore funded extra capital accumulation of the same value as the external imbalance.

It may be argued that the conventional saving measure is understated if unadjusted for alternative expenditure concepts. For example, expenditure on education, research and development, certain defence equipment and consumer durables (treated as consumption expenditure in the national accounts) may be treated as investment as they contribute to future production of goods and services.

If such expenditure is reclassified as investment, measures of either gross or net domestic saving and investment would rise accordingly (see Australian Bureau of Statistics, - ABS, 2002). Again however, the difference between adjusted saving and investment would equate to the same-sized external imbalance derived from the conventional saving measure.

High current account deficits have raised net foreign debt from 35 per cent of GDP at the beginning of the 1990s to around 50 per cent at the end of 2004. The private sector owns nearly all of this debt and around 80 per cent of external borrowing is intermediated through financial institutions, mainly the major commercial banks. 
Figure 1: Saving, Investment and the External Imbalance: Australia vs OECD Average
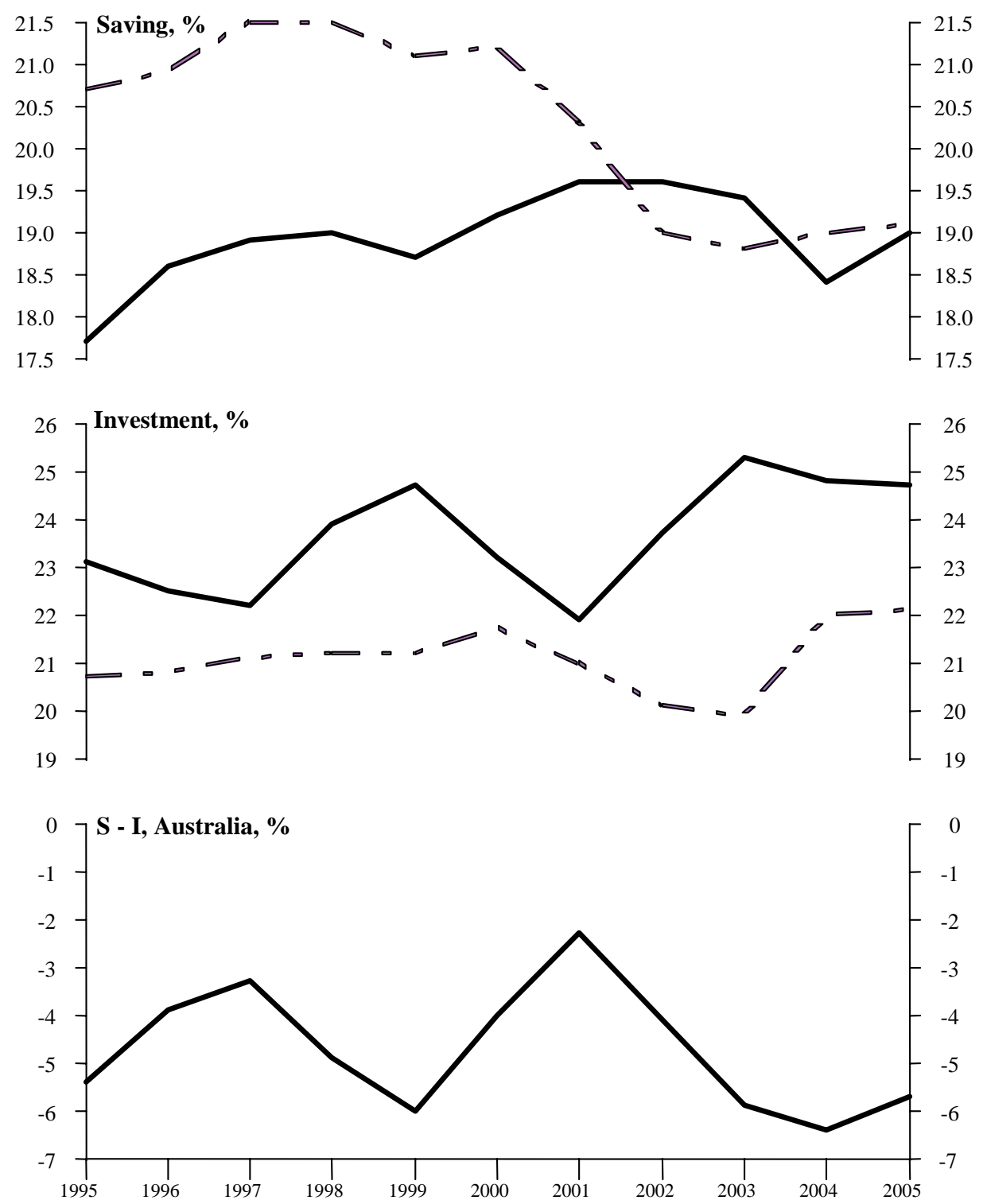

Source: Data from International Monetary Fund, World Economic Outlook (various years) 
Meanwhile, net external equity inflows increased net external liabilities to 65 per cent of GDP. Although Australia now has a high level of external liabilities to the rest of the world, a much greater rise in private wealth due to capital accumulation and valuation gains have ensured that net external liabilities are still only around 10 per cent of the total value of residents' assets.

\section{National Income Gains from Foreign Capital}

If Australia's external imbalances signify additional capital accumulation, how does this affect economic growth? This depends on the relationship between domestic saving, foreign investment, domestic investment and the production process.

When foreigners finance expansion of the domestic capital stock, the rise in external liabilities is also matched by an increase in the nation's real assets. In short, foreign investment supplements domestic saving, allowing an economy to accumulate real capital more quickly. Without that capital inflow over past decades, the combined saving of the private and public sectors would have yielded lower investment and hence lower real output growth.

Therefore, the question of the desirability of a current account deficit, which necessarily matches a net capital inflow, essentially depends on whether the extra real output made possible by foreign finance exceeds the real servicing cost on that source of finance.

Standard growth accounting (see Solow, 1956; 1957) suggests that to understand how national output and income grow, it is necessary to focus on the main factor inputs to economy-wide production. Conventionally, these factor inputs have been the domestic labour force, the domestic capital stock and multifactor productivity, inclusive of disembodied technological change.

Within a traditional growth accounting framework, a distinction can be made between home-funded and foreign-funded capital accumulation for financially open economies. In international borrower economies the real capital stock comprises capital funded by domestic saving and additional capital accumulated via external borrowing.

Hence, in an open economy the macroeconomic production function may be specified as

$$
Y=f\left(A, K, K^{*}, L\right)
$$

where $Y$ is national output or $G D P, A$ is a technology parameter representing disembodied technical change, $K$ is domestically funded capital accumulation, $K^{*}$ is foreign-financed investment and $L$ is labour hours worked.

By totally differentiating this open economy production function, the sources of increased gross domestic product are shown to be

$$
d Y=f_{A} d A+f_{K} d K+f_{K^{*}} d K^{*}+f_{L} d L
$$

where $f_{A, K, K^{*}, L}$ denotes the derivative of $Y$ with respect to $A, K, K^{*}, L$. 
For economies that are net borrowers, national output and national disposable income diverge to the extent of net income paid abroad. Hence,

$$
Y_{n}=Y-r^{*} K^{*}
$$

where $Y_{n}$ is national disposable income and $r^{*}$ is the effective servicing cost of foreign capital (inclusive of dividends) on external liabilities. So,

$$
d Y_{n}=d Y-\left(r^{*} d K^{*}+d r^{*} K^{*}\right)
$$

The effective interest rate paid to foreigners may vary from interval to interval as world interest rates fluctuate or as any risk premium varies through time.

From (2) and (4), the sources of national income growth can therefore be shown as

$$
d Y_{n}=\left\{f_{A} d A+f_{L} d L+f_{K} d K\right\}+\left\{f_{K^{*}} d K^{*}-\left(r^{*} d K^{*}+d r^{*} K^{*}\right)\right\}
$$

The first set of braces captures the domestic sources of growth whereas the second set includes the foreign sources of central interest. Hence, national income gains can be attributed to domestic sources, $d Y_{n}^{d}$, and foreign sources, $d Y_{n}^{f}$, such that

$$
d Y_{n}=d Y_{n}^{d}+d Y_{n}^{f}
$$

Dividing through by national income, National Income Growth = Domestic Contribution + Foreign Contribution $(7)$

To estimate the net contribution of foreign capital, it is necessary to derive values in real terms for each of the variables in the expression

$$
\left(f_{K^{*}}-r^{*}\right) d K^{*}-d r^{*} K^{*}
$$

where $K^{*}$ represents the capital funded from abroad.

Since most capital inflow is intermediated through the commercial banking system, it is reasonable to assume that the productivity of capital in use domestically is invariant to the source of its funding. Therefore,

$$
f_{K}=f_{K^{*}}
$$

Next, we assume output is generated by a Cobb-Douglas function of the form

$$
Y=A K^{\alpha} L^{1-\alpha}
$$

where $\alpha$ is the share of capital in national income.

The Cobb-Douglas function remains a popular specification of the production process in international studies and this form is appropriate if the division of national income between capital and labour has been roughly constant over an extended period of time. As we will see shortly, this indeed has been the experience for Australia over the past decade.

When differentiated with respect to capital, the Cobb-Douglas production function yields

$$
f_{K}=\alpha A K^{\alpha-1} L^{1-\alpha}
$$

Dividing (10) by $K$, 


$$
\frac{Y}{K}=A K^{\alpha-1} L^{1-\alpha}
$$

Hence,

$$
f_{K}=\alpha A K^{\alpha-1} L^{\alpha-1}=\alpha \frac{Y}{K}
$$

The marginal product of capital in use domestically is therefore the income share of capital in GDP times the ratio of national output to capital.

\section{Estimates of National Income Gains}

Using the comprehensive flow and stock data from the national accounts, it is possible to derive annual values of the marginal product of capital for each of the past ten years using expression (13). The data required for this purpose are included in Table 1.

\begin{tabular}{|c|c|c|c|c|c|c|c|}
\hline & $\begin{array}{c}\text { Real } \\
\text { Capital } \\
\text { Stock (a) }\end{array}$ & $\begin{array}{l}\text { Real } \\
\text { GDP } \\
\text { (b) }\end{array}$ & $\begin{array}{l}\text { Output/ } \\
\text { Capital } \\
\text { Ratio(c) }\end{array}$ & $\begin{array}{l}\text { Capital } \\
\text { Share } \\
\text { (d) }\end{array}$ & $\begin{array}{l}\text { Marginal } \\
\text { Product of } \\
\text { Capital (e) }\end{array}$ & $\begin{array}{c}\text { Capital } \\
\text { Consumption } \\
(f)\end{array}$ & $\begin{array}{c}\text { Net Marginal } \\
\text { Product of } \\
\text { Capital }(g)\end{array}$ \\
\hline Year & $(\$ b)$ & $(\$ b)$ & & $(\%)$ & & $(\%)$ & $(\%)$ \\
\hline 1995-96 & 1806.0 & 621.8 & 0.34 & 0.39 & 13.3 & 4.7 & 8.5 \\
\hline 1996-97 & 1857.6 & 646.0 & 0.35 & 0.37 & 12.9 & 4.7 & 8.2 \\
\hline $1997-98$ & 1918.2 & 674.9 & 0.35 & 0.38 & 13.5 & 4.8 & 8.7 \\
\hline 1998-99 & 1981.0 & 709.9 & 0.36 & 0.38 & 13.5 & 4.9 & 8.6 \\
\hline 1999-00 & 2050.6 & 738.1 & 0.36 & 0.38 & 13.7 & 5.0 & 8.8 \\
\hline 2000-01 & 2098.5 & 752.4 & 0.36 & 0.38 & 13.7 & 5.0 & 8.7 \\
\hline 2001-02 & 2155.6 & 780.8 & 0.36 & 0.39 & 14.1 & 5.1 & 8.9 \\
\hline 2002-03 & 2231.8 & 806.2 & 0.36 & 0.39 & 14.1 & 5.2 & 8.9 \\
\hline 2003-04 & 2318.3 & 838.3 & 0.36 & 0.40 & 14.4 & 5.2 & 9.2 \\
\hline 2004-05 & 2407.9 & 857.8 & 0.36 & 0.40 & 14.3 & 5.2 & 9.1 \\
\hline
\end{tabular}

Table 1: Estimating Marginal Product of Capital, 1995-96 to 2004-05

Notes:

$\mathrm{a}=$ capital stock chain volume data in 2003-04 prices from ABS (2005:83, Table 69).

$\mathrm{b}=$ GDP chain volume data in 2003-04 prices from ABS (2005:16, Table 2).

$\mathrm{c}=$ ratio of the real capital stock to real gross domestic product.

$\mathrm{d}=$ ratio of gross operating surplus to the sum of compensation of employees and gross operating surplus; data from ABS (2005:26, Table 12).

$\mathrm{e}=$ product of the output-capital ratio and the capital share of income.

$\mathrm{f}=$ estimated as the ratio of chain volume measures of consumption of fixed capital to end-year capital stock; data from ABS (2005:84, Table 69).

$\mathrm{g}=$ difference between the marginal product of capital and the estimated depreciation rate. 
These data reveal minimal variation in the output/capital ratio and in the income share of capital in GDP, although there was a slight rise in the rate of capital consumption. Capital consumption now accounts for over half of gross investment and the higher rate of depreciation most likely reflects more intensive use of computers and information technology whose write-off period has diminished as innovation has intensified.

From equation (13), the marginal product of capital results from multiplying the capital share of income and output/capital ratio. Net of depreciation, this yields annual values within the narrow range 8.2-9.2 per cent over the decade. These real values (in constant 2003-04 prices) can then be combined with estimates of the real effective cost of foreign capital and the real external imbalance to yield real annual national income gains attributable to foreign capital.

To estimate the real servicing cost of capital, it is first necessary to derive implicitly the nominal effective cost of foreign capital using balance of payments and international investment position data. The implicit foreign interest rate is net interest paid abroad, as recorded in the current account balance, divided by the stock of net external debt as shown in Figure 2.

International evidence suggests that interest paid abroad is positively related to the stock of foreign debt giving rise to a risk premium (Orr, Edey and Kennedy, 1995; and Lane and Milesi-Ferretti, 2002). A rising risk premium in Australia's case would, other things equal, increase interest paid abroad and hence be reflected in the implicit foreign interest rate.

Apart from debt, external liabilities are in the form of equities serviced through dividends and the profits of branches of transnational companies. Hence, to derive the total effective cost of foreign capital these payments are combined with interest paid abroad and divided by the weighted stock of net foreign liabilities, inclusive of equity investment.

Figure 2 shows that the total effective measure persistently exceeded the effective interest rate on foreign debt in nominal terms over the period, implying an 'equity premium' existed for foreign investors in Australia. This equity premium has widened significantly over recent years as the effective interest rate fell in line with global interest rates, thereby ensuring little variation in the nominal cost of foreign capital. 
Figure 2: Implicit Foreign Interest Rate and Cost of Foreign Capital, 1995-96 to 2004-05

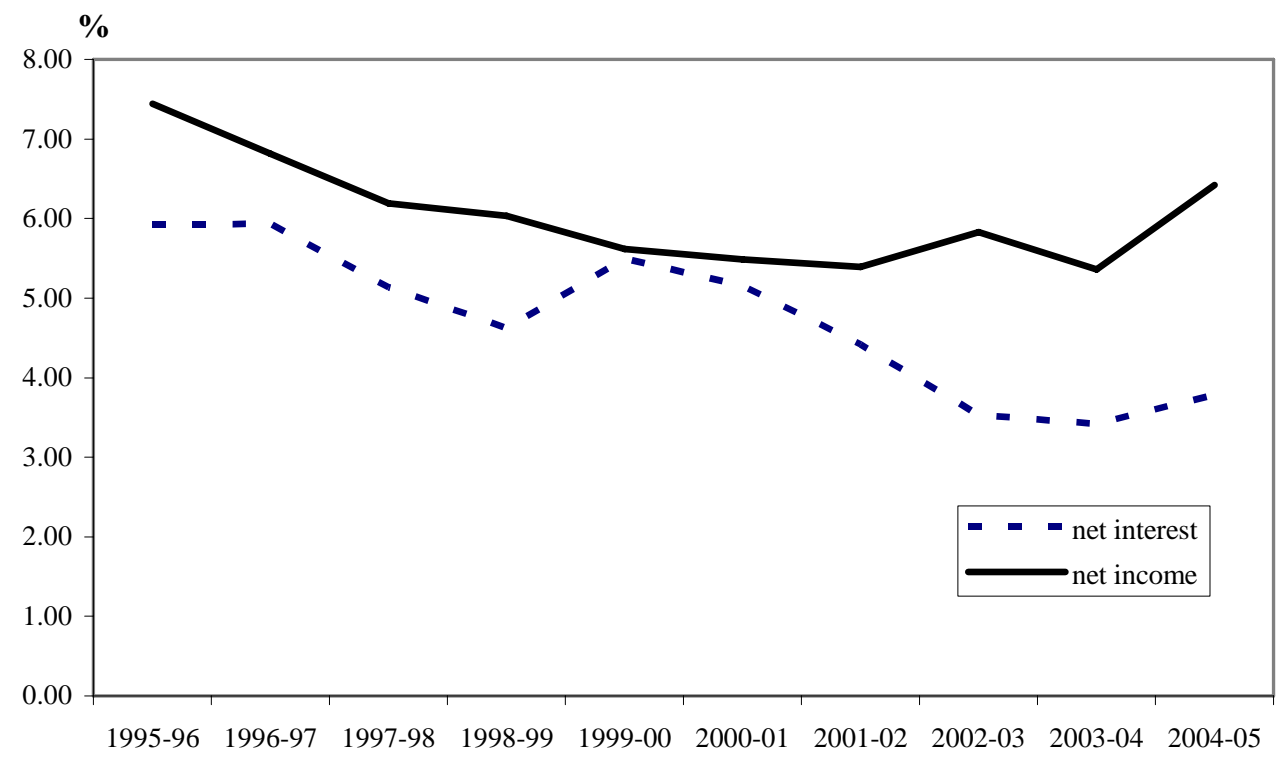

Notes:

$\mathrm{a}=$ based on data from Reserve Bank of Australia, Bulletin, Tables H5 and H7.

$\mathrm{b}=$ since the stock of debt changes through the year, the value of net external debt in the denominator should be a weighted average. The Australian Bureau of Statistics recommends a weights of two-thirds and one third respectively for beginning and of year values.

Table 2 presents estimates of the additional national income generated annually by foreign-financed capital that has accumulated over the past decade. In every year it is evident that the marginal product of foreign capital exceeded its servicing cost, the difference averaging over five per cent for the period.

This is not the full story however, because the earlier relation (13) underpinning this estimation exercise also implies that further national income gains or losses arise from period-to-period movements in the implicit interest rate as applied to the stock of foreign debt. In other words, the total servicing cost of foreign capital also rises or falls from year to year as the foreign interest rate varies. Foreign interest rate falls add to net income gains, whereas rises, inclusive of any increase in interest risk premiums charged by foreign lenders, subtracts from net income gains. 
Table 2: National Income Gains from Annual Foreign Capital Inflow

\begin{tabular}{l|cccccc}
\hline & $\begin{array}{c}\text { Net Foreign } \\
\text { Liabilities }(a)\end{array}$ & $\begin{array}{c}\text { Net Income } \\
\text { Payments } \\
\text { Abroad }(b)\end{array}$ & $\begin{array}{c}\text { Real Cost of } \\
\text { Foreign } \\
\text { Capital }(c)\end{array}$ & $\begin{array}{c}\text { Net Marginal } \\
\text { Product Less } \\
\text { Real Cost }(d)\end{array}$ & $\begin{array}{c}\text { Real CAB } \\
(e)\end{array}$ & $\begin{array}{c}\text { Real National } \\
\text { Income Gain } \\
(f)\end{array}$ \\
\hline Year & $(\$ b)$ & $(\$ b)$ & $(\%)$ & $(\%)$ & $(\$ b)$ & $(\$ b)$ \\
$1995-96$ & 262.0 & 19.5 & 4.0 & 4.5 & 24.7 & 1.1 \\
$1996-97$ & 280.2 & 19.1 & 5.4 & 2.8 & 19.6 & 0.5 \\
$1997-98$ & 292.4 & 18.1 & 4.7 & 4.0 & 25.2 & 1.0 \\
$1998-99$ & 305.1 & 18.4 & 4.4 & 4.2 & 36.5 & 1.5 \\
$1999-00$ & 324.0 & 18.2 & 3.2 & 5.6 & 35.2 & 2.0 \\
$2000-01$ & 340.9 & 18.7 & -0.4 & 9.1 & 18.7 & 1.7 \\
$2001-02$ & 365.5 & 19.7 & 2.3 & 6.6 & 21.4 & 1.4 \\
$2002-03$ & 386.0 & 22.5 & 3.8 & 5.1 & 42.0 & 2.1 \\
$2003-04$ & 442.1 & 23.7 & 4.2 & 5.0 & 47.8 & 2.4 \\
$2004-05$ & 485.8 & 31.2 & 4.6 & 4.5 & 56.1 & 2.5 \\
\hline
\end{tabular}

Notes:

$\mathrm{a}=$ weighted average measures of net foreign liabilities based on data in current prices from Reserve Bank of Australia, Bulletin, Table H5.

$\mathrm{b}=$ current price data from Reserve Bank of Australia, Bulletin, Table H7.

$\mathrm{c}=$ ex post real cost of foreign capital is the ratio of net income payments to net foreign liabilities less annual inflation rate; inflation data from Reserve Bank of Australia, Bulletin, Table G1.

$\mathrm{d}=$ the difference between the net marginal product of capital from Table 1 and the real cost of foreign capital.

e = external account imbalances from ABS (2005:18, Table1) expressed in 2003-04 prices after deflating by the Implicit Price Deflator for investment from ABS (2002:22, Table 8).

$\mathrm{f}=$ the product of the net marginal product of foreign capital less real servicing cost and the external imbalance in 2003-04 prices.

Year to year interest rate movements stem from changes in world interest rates, exchange rate swings affecting foreign currency denominated debt and any interest risk premium that may vary through time. Accordingly, Table 3 presents estimates of national income gains or losses arising from changes in the implicit foreign interest rate. World interest rates generally fell over the decade. Hence these interest-related income gains generally augment those shown in Table 2.

As the average age of capital is seventeen years, the new capital installed at the start of the decade in review could be expected to generate income throughout the entire period. For this reason the gains should also be considered cumulatively. On this basis, the extra real income stemming from foreign-funded 
capital over the decade was $\$ 23.3$ billion in constant prices, or $\$ 24.2$ billion in 2004-05 prices.

Table 3: Total National Income Gains from Foreign Capital

\begin{tabular}{c|cccccc}
\hline & $\begin{array}{c}\text { Change in } \\
\text { Implicit Foreign } \\
\text { Interest Rate }(a)\end{array}$ & $\begin{array}{c}\text { Income Gain } \\
\text { from Interest } \\
\text { Rate } \\
\text { Movements }(b)\end{array}$ & $\begin{array}{c}\text { Real Income } \\
\text { Gain from } \\
\text { Interest Rate } \\
\text { Movements }(c)\end{array}$ & $\begin{array}{c}\text { National Income } \\
\text { Gain from } \\
\text { Foreign Capital } \\
\text { (from Table 2) }\end{array}$ & $\begin{array}{c}\text { Total National } \\
\text { Income Gain } \\
(2003-04 \\
\text { prices) }(d)\end{array}$ & $\begin{array}{c}\text { Cumulative } \\
\text { Income Gain } \\
(2003-04 \\
\text { prices })\end{array}$ \\
\hline Year & $(\%)$ & $(\$ b)$ & $(\$ b)$ & $(\$ b)$ & $(\$ b)$ & $(\$ b)$ \\
$1995-96$ & 1.1 & 0.9 & 1.6 & 1.1 & 2.7 & 2.7 \\
$1996-97$ & 0.0 & 0.0 & 0.0 & 0.5 & 0.5 & 3.2 \\
$1997-98$ & 0.8 & 1.7 & 1.5 & 1.0 & 2.5 & 5.7 \\
$1998-99$ & 0.5 & 1.2 & 1.0 & 1.5 & 2.5 & 8.2 \\
$1999-00$ & -0.9 & -2.1 & -1.9 & 2.0 & 0.1 & 8.3 \\
$2000-01$ & 0.3 & 1.0 & 0.9 & 1.7 & 2.6 & 10.9 \\
$2001-02$ & 0.7 & 2.3 & 2.2 & 1.4 & 3.6 & 14.5 \\
$2002-03$ & 0.9 & 3.0 & 2.9 & 2.1 & 5.0 & 19.5 \\
$2003-04$ & 0.1 & 0.4 & 0.4 & 2.4 & 2.8 & 22.3 \\
$2004-05$ & -0.4 & -1.5 & -1.6 & 2.5 & 1.0 & 23.3 \\
\hline
\end{tabular}

Notes:

(a) the year to year change in the implicit foreign interest rate derived in Figure 4; data from Reserve Bank of Australia, Bulletin, Tables H5 and H7.

(b) the product of the weighted stock of net foreign debt and the change in the implicit foreign interest rate; data from Reserve Bank of Australia, Bulletin, Tables H5 and H7.

(c) the value of the income gain from interest rate changes deflated by the Implicit Price Deflator for Gross Domestic Product.

(d) the sum of the real national income gain from annual foreign capital inflow from Table 2 plus the real annual net gain from interest rate movements.

With a total workforce of around 9.8 million people in mid-2004-05, income per employed person in Australia was therefore approximately \$2,500 higher in 2004-05 prices than it would have been without the net capital inflow that occurred between 1995-96 and 2004-05. With a total population around 20.5 million at the time, national income per head was close to $\$ 1,100$ higher due to foreign capital inflow over the previous decade.

While these results attest to the benefits of capital inflow to Australia, they do not imply that foreign-funded investment generated no losses or bankruptcies at the firm level over the period. If unproductive capital results in widespread losses in any year, the value of the net marginal cost less foreign servicing cost would conceivably be much lower. Under such circumstances financial crisis and recession could result, especially if accompanied by rising interest rates. Such 
crises occasionally occur in emerging economies that borrow unsoundly at a premium (see Eichengreen, 2002; Glick, Moreno and Spiegel, 2001).

The macroeconomic methods and assumptions used above are of course subject to the standard criticisms that aggregative approaches attract. For instance, at the microeconomic level, saving and investment may be subject to various distortions that render them sub-optimal and domestic and foreign capital controls could affect the volume of capital inflows. Yet, the economy-wide impact of microeconomic distortions are difficult to assess and should significant ones exist, could have offsetting effects on the variables of most interest here. Microeconomic factors are therefore considered of second-order importance in this context.

It may be that other functional forms of macroeconomic production, such as the CES production function, better reflect the relationship between labour and capital in the Australian context (for instance with respect to the substitutability of labour and capital). Examining whether alternatives to the Cobb-Douglas specification of output generation used here could be adapted to reconfirm the above estimates of national income gains from foreign capital inflow to Australia is a worthy topic for future research. Whether dwelling investment should be treated in the same way as other forms of investment may also warrant further consideration in this context.

\section{Concluding Comments}

This paper has argued that persistent external deficits are symptomatic of a growth process in which the rate of capital accumulation exceeds the overall saving rate. By explicitly identifying the contribution of foreign capital to national income growth, it has shown that Australia's national income grew significantly faster due to the large current account deficits and higher debt levels of the past decade, yielding additional income on average of around $\$ 2,500$ per worker.

At the same time, there is a risk that future income gains could diminish if world interest rates keep rising or if a higher interest risk premium emerged. Indeed, the above estimates show that sometimes annual movements in the implicit foreign interest rate have been at least as significant as new foreign capital inflow as a source of variation in national income. Other things equal, an implicit interest rate in 2004-05 that was only 65 basis points higher would have been sufficient to offset the gain from capital inflow that year.

It may be argued that in the absence of capital inflow, domestic interest rates and hence domestic saving and domestic capital accumulation would have been higher. Yet there is little evidence of a strong relationship between interest rates and domestic consumption and saving in theory (standard textbook models for instance do not include interest rates in consumption functions) or empirically (see International Monetary Fund, 2005). Moreover, without capital inflow higher interest rates would have resulted in a smaller capital stock and hence national output. 
On balance, the annual income gains over the decade most likely understate the total contribution of foreign capital and should be considered minimum values. This is because part of capital inflow is direct foreign investment which entails the transfer of technology, work practices and management techniques that boost multifactor productivity. Hence, part of the multifactor productivity improvement over this time would be attributable to foreign capital rather than exclusively to domestic sources. Unfortunately, it is difficult to quantify exactly how much this would add to the foreign-contribution component of annual income growth.

Nonetheless, the straightforward method and benchmark estimates of the benefits of current account deficits and capital inflow over the past decade add a new dimension to the rekindled debate about the significance of Australia's external position.

\section{References}

Australian Bureau of Statistics (2005), Australian System of National Accounts, 2004-05, Cat 5204.0, Canberra.

Australian Bureau of Statistics (2002), 'Saving, Borrowing, Investment and Wealth', Special Article in Australian System of National Accounts, 2000-01, Cat 5204.0, Canberra.

Australian Bureau of Statistics (2005), Balance of Payments and International Investment Position, Australia, Cat 5302.0, Canberra.

Edwards, J. (2005), 'Uncomfortable Arithmetic', HSBC Australia and New Zealand Weekly, 6 June.

Eichengreen, B. (2002), Financial Crises and What to Do About Them, Oxford University Press, Oxford, UK.

Fischer, S. (2003), 'Financial Crises and Reform of the International Financial System' Weltwirtschaftliches Archiv, 139(1):1-37.

Frenkel, J., and A. Razin (1987), Fiscal Policies and the World Economy, MIT Press, Cambridge, Massachusetts.

Glick, R., R. Moreno and M. Spiegel, (2001) Financial Crises in Emerging Markets, Cambridge University Press, Cambridge, UK.

Grubel, H. (1987), 'Foreign Investment', pp. 403-6 in J. Eatwell, M. Milgate and P. Newman (eds), The New Palgrave Dictionary of Economics, vol. 2, Macmillan, London.

International Monetary Fund (2005 and earlier years) World Economic Outlook, IMF, Washington DC.

Lane, P. and G. Milesi-Ferretti (2002), 'Long-Term Capital Movements,' 73-116 in B. Bernanke and K. Rogoff (eds) NBER Macroeconomics Annual 2001, MIT Press, Cambridge, Massachusetts.

MacDougall, G. (1960), 'The Benefits and Costs of Private Investment from Abroad: A Theoretical Approach’, Economic Record March (Special Issue):13-35. 
Macfarlane, I. (2005) 'What are the Global Imbalamces?', Talk to Economic Society of Australia Dinner, Melbourne, 28 September, http://www.rba.gov.au/Speeches/2005/.

Makin, A. (2003), Global Finance and the Macroeconomy, Palgrave Macmillan, New York.

Makin, A. (1989), "Is the Current Account Deficit Sustainable?” Australian Economic Review (2nd quarter):29-33.

Mann, C. (2002), 'Perspectives on the US Current Account Deficit and Sustainability', Journal of Economic Perspectives 16(3):131-152.

Orr, A, M. Edey and M. Kennedy (1995), 'Real Long-term Interest Rates: The Evidence from Pooled-Time-Series’, OECD Economic Studies 25(2):76-107.

Reserve Bank of Australia, Bulletin, http://www.rba.gov.au/Statistics/

Ruffin, R. (1984), 'International Factor Movements’, pp. 237-88 in P. Kenen and R. Jones (eds), Handbook of International Economics vol. 1(Ch 5), North-Holland, Amsterdam.

Solow, R. (1956) 'A Contribution to the Theory of Economic Growth', Quarterly Journal of Economics 70:65-94.

Solow, R. (1957), 'Technical Change and the Aggregate Production Function', Review of Economics and Statistics 39(August):312-320.

Swan, W. (2005), ‘Australia’s Economic Challenges', Address to Australian Fabian Society National Policy Conference, Melbourne, 11 November, http://www.swanmp.org/.

The author is grateful to the Editor, Graeme Wells, and an anonymous referee for insightful and constructive comments. 